\title{
Parainfluenza Type 3 Virus as an Etiological Cause of Acute Urticaria
}

\author{
(1) Öner Özdemir,' (ㄷ) Ece Cansu Okur²
}

\author{
'Department of Pediatric Allergy \\ and Immunology, Sakarya University \\ Faculty of Medicine Research and \\ Training Hospital, Sakarya, Turkey \\ ${ }^{2}$ Department of Pediatrics, Sakarya \\ University Faculty of Medicine \\ Research and Training Hospital, \\ Sakarya, Turkey \\ Submitted: 20.11.2019 \\ Accepted: 17.02.2020 \\ Correspondence: Öner Özdemir \\ Sakarya Üniversitesi Tıp Fakültesi \\ Eğitim ve Araştırma Hastanesi, \\ Çocuk Allerji-İmmünoloji Bilim Dalı, \\ Sakarya, Turkey \\ E-mail: oner.ozdemir.md@gmail.com

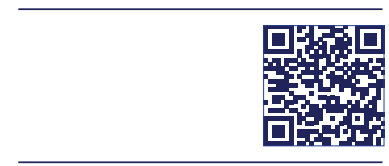 \\ Keywords: Acute urticaria; \\ bronchiolitis; parainfluenza. \\ This work is licensed under a Creative Commons \\ Attribution-NonCommercial 4.0 International License.
}

\begin{abstract}
Presently described is the case of an II-month-old-girl diagnosed with acute urticaria due to parainfluenza virus type 3 (PIV-3). This rare etiological agent of urticaria was isolated from a nasopharyngeal swab after the development of bronchiolitis. The patient had received treatment at another clinic for a maculopapular skin eruption, rhinorrhea, fever, and a cough; however, after a lack of response and a progression of symptoms, she was brought to our pediatric allergy and immunology polyclinic. A physical examination revealed diffuse and resistant urticarial plaques on the body and she was admitted for further evaluation and therapy. Bronchiolitis developed and auscultation on the second day of admission revealed bilateral subcrepitant rales and wheezing. Treatment with salbutamol $6 \times 0.15 \mathrm{mg} / \mathrm{kg} / \mathrm{dose}$ was initiated, and pheniramine $1.4 \mathrm{mg} / \mathrm{kg} /$ day (in 2 doses) and ranitidine $2 \mathrm{mg} / \mathrm{kg} /$ day (in 2 doses) were added for the urticaria. PIV-3 was isolated from a nasopharyngeal swab. It is important to remember that viral infections can have a significant role in the etiology of acute urticaria in childhood. A detailed medical history and laboratory evaluations for infection may be needed for a thorough differential diagnosis and evaluation of etiological factors in urticarial disease.
\end{abstract}

\section{INTRODUCTION}

Urticaria is a disease that usually progresses with itchy and edematous papules/plaques on the epidermis and occasionally with angioedema as a result of involvement of the deep dermis or subcutis. ${ }^{[l]}$ Acute urticaria (AU) develops suddenly and is characterized by swollen, erythematous plaques accompanied by an itching or burning sensation lasting 30 minutes to 24 hours. ${ }^{[2]}$ Symptoms persisting for more than 6 weeks are classified as chronic urticaria $(\mathrm{CU}) .{ }^{[3]}$ The frequency of urticaria in children has been reported to be between $2 \%$ and $6.7 \% .^{[4,5]} \mathrm{Al}-$ though the etiology of $A U$ in childhood often cannot be determined, acute viral/bacterial infection, and drug and food interactions are among the most common causes. ${ }^{[1-5]} \mathrm{AU}$ is often seen in cases of viral respiratory tract infection, as well as during acute gastroenteritis, acute pharyngitis, and urinary tract infection. The most common lower respiratory tract infection in childhood is acute bronchiolitis, which is frequently caused by viral pathogens.
Parainfluenza virus type 3 (PIV-3) causes upper respiratory tract disease and can be epidemic worldwide in the spring months. It was first isolated in newborns with croup (laryngo-tracheo-bronchitis) in 1955. Almost half of all children become infected with PIV-3 within the first year of life, but reinfection with PIV has also been frequently reported. Among the viruses that cause respiratory infections in young children, PIV is the most common cause of hospitalization after respiratory syncytial virus (RSV) and PIV-3 is the most common cause of bronchiolitis and pneumonia after RSV. ${ }^{[6]}$

Described here is a case of PIV-3 discovered in an I I-month-old female patient who was presented with AU.

\section{CASE REPORT}

An II-month-old female patient had a maculo-papular rash covering her whole body that had been present for I week, and additional symptoms of a cold, fever, and cough that began on the second day of the rash. The patient was initially diagnosed at another medical center 

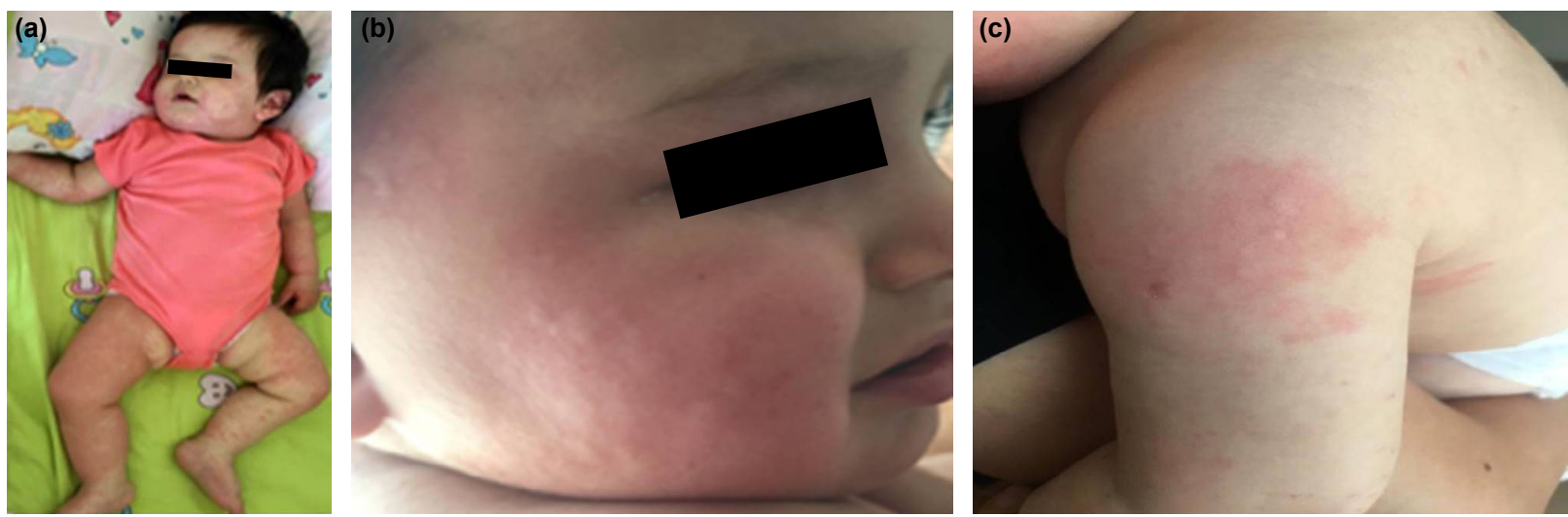

Figure 1. (a) Widespread maculo-papular rash seen on the body of the patient. (b) Urticarial rash seen on the face of the patient. (c) Urticarial rash seen on the left arm of the patient.

with scarlet fever due to the significant rash, (Fig. Ia) and ampicillin-sulbactam, cetirizine, and methylprednisolone treatment was initiated. She was brought to the Sakarya University Hospital Pediatric Allergy and Immunology outpatient clinic because her rash had worsened after I week of treatment. A physical examination at our facility (Fig. Ib, c) revealed widespread urticarial rash on the face, trunk, and extremities, and she was admitted for further examination and treatment. There was no known relevant disease in the patient or family history. A respiratory system examination revealed that the lungs were bilaterally equally ventilated and respiratory sounds were normal. After bronchiolitis developed on the second day of hospitalization, salbutamol $6 \times 0.15 \mathrm{mg} / \mathrm{kg} /$ nebule was initiated due to bilateral subcrepitant rales and wheezing. Pheniramine $1.4 \mathrm{mg} / \mathrm{kg} / \mathrm{day}$ (in 2 doses) and ranitidine 2 $\mathrm{mg} / \mathrm{kg} / \mathrm{day}$ (in 2 doses) therapy was initiated for the urticaria. Other system examination results were normal. Pheniramine, ranitidine, and salbutamol treatment was gradually reduced following the regression of the urticarial rash and improvement of lung auscultation findings. On the sixth day of hospitalization, the patient's general condition had continued to improve and she was discharged with a recommendation for outpatient clinic follow-up.

The laboratory examination results were hemoglobin: $11.1 \mathrm{~g} / \mathrm{dL}$, hematocrit: $32.9 \%$, leukocyte count: $5310 / \mathrm{mm}^{3}$ (neutrophil: $34.4 \%$, lymphocyte: $58.9 \%$ ). Routine biochemical test results were within the normal limits. The $\mathrm{C}$-reactive protein (CRP) level was $<3.02 \mathrm{mg} / \mathrm{L}$ (normal: $0-5$ ), the erythrocyte sedimentation rate was $20 \mathrm{~mm} / \mathrm{hour}$, and a complete urinalysis, stool microscopy, and parasite examination were normal. A nasal swab was used to perform a respiratory panel to detect viral-bacterial agents. A total of 18 viruses from 9 virus groups (influenza, rhinovirus, coronavirus, PIV, human metapneumovirus $A / B$, bocavirus, RSV, adenovirus, and enterovirus) were screened, and PIV3 was isolated.

Verbal consent for the presentation of this case was obtained from the father of the patient.

\section{DISCUSSION}

$A U$ is characterized by itchy and edematous plaques that appear suddenly and spontaneously resolve within the same day. Rarely, urticaria can persist, and after 6 weeks it is classified as CU. The cause is only determined in $20 \%$ of cases. ${ }^{[7]}$ Nearly half of urticaria cases are accompanied by angioedema. ${ }^{[2,8]}$ The rash observed in our patient was initially confused with scarlet fever rash at another center, and antihistamine and steroid treatment was provided, in addition to antibiotics. The diagnosis of urticaria became clear once it was seen that the rash came and went within a few hours during the day. There was no accompanying angioedema in this case.

The diagnosis of urticaria can usually be made with a detailed anamnesis and clinical findings, however, it is often difficult to identify etiological factors. The anamnesis should include a history of drug use, infection, nutrition, use of food additives, insect bites, connective tissue diseases, and physical agents. In this case, other than a history of a respiratory tract infection, no other pathology related to $A U$ etiology was identified.

PIV-3 was detected when a respiratory panel was requested after bronchiolitis developed following presentation with a rash and an upper respiratory tract infection. These are symptoms of the same disease at different stages. The initial and subsequent clinical picture of the patient was thought to be due to a single virus and the AU was linked to PIV-3.

With the exception of some very basic tests (hemogram, CRP, complete urine and stool examination) performed for the differential diagnosis of the rash (urticaria), no detailed investigation was conducted, as is the recommendation according to the guidelines and literature reports regarding $A \cup U^{[1,2]}$ Generally, these rashes are thought to be caused by common childhood viral infections. ${ }^{[-5]}$ The present patient's plaques were raised and surrounded by redness, and should not have been confused with either a scarlet fever or measles rash. In addition, the patient was young for scarlet fever and there was no sign of Koplik's spots, which are pathognomonic for measles. 
Successful detection of the causative agent of urticaria can vary between $21 \%$ and $83 \% .{ }^{[9]}$ The incidence of atopy in pediatric patients with urticaria is greater than that of the general population, however, there was no history of atopy in this case.

Studies have demonstrated that infectious pathogens are the most important factors in $\mathrm{AU}$ and $\mathrm{CU}$. Liu et al. ${ }^{\left[{ }^{[0]}\right.}$ retrospectively examined 953 patients who were admitted to a pediatric emergency outpatient clinic for $A U$ in 2008 and found that the most important cause of urticaria in infancy was infection (56.5\%) and that the prevalence of infection decreased as the age group got older $(51.2 \%$ in preschool children, $42.1 \%$ in school-age children, and $17.1 \%$ in adolescents). The presence of symptoms of a respiratory tract infection and the isolation of PIV-3 in a nasopharyngeal swab sample supported the conclusion that the AU etiology was infection. Although it has been reported in the literature that viral pathogens are one of the most common factors in $\mathrm{AU}$ etiology, a literature review did not disclose research indicating that PIV-3 had been a factor in urticaria. ${ }^{[1]}$

The goal of treatment for urticaria is to eliminate etiological causes and to relieve symptoms. The use of systemic antihistamines and systemic steroids is recommended for symptomatic treatment. ${ }^{[2]}$ Second-generation $\mathrm{HI}$ antihistaminic agents are generally recommended in the treatment of $\mathrm{AU}$. Patients with persistent, uncontrolled symptoms may be transitioned to another $\mathrm{HI}$ or $\mathrm{H} 2$ antihistamine agent. Resolution was seen in this case with first-generation $\mathrm{HI}$ receptor antagonist (pheniramine) and $\mathrm{H} 2$ receptor antagonist (ranitidine) treatment initiated when the urticaria did not improve with cetirizine and methylprednisolone.

\section{CONCLUSION}

It is important to remember that infection may play a role in the etiology of AU. In cases of urticaria in childhood, a detailed anamnesis of potentially underlying etiological factors and tests for infection can be very valuable.

\section{Informed Consent}

Written informed consent was obtained from the patient's parent for publishing the case report and accompanying images.

Peer-review

Internally peer-reviewed.

Authorship Contributions

Concept: Ö.Ö., E.C.O.; Design: Ö.Ö., E.C.O.; Supervision: Ö.Ö., E.C.O.; Fundings: Ö.Ö.; Materials: Ö.Ö.; Data: E.C.O.; Analysis: Ö.Ö.; Literature search: E.C.O.; Writing: Ö.Ö., E.C.O.; Critical revision: Ö.Ö.

Conflict of Interest

None declared.

\section{REFERENCES}

1. Zuberbier T, Aberer W, Asero R, Bindslev-Jensen C, Brzoza Z, Canonica GW, et al. The EAACI/GA(2)LEN/EDF/WAO Guideline for the definition, classification, diagnosis, and management of urticaria: the 2013 revision and update. Allergy 2014;69:868-87. [CrossRef]

2. Zuberbier T, Asero R, Bindslev-Jensen C, Walter Canonica G, Church MK, Giménez-Arnau A, et al. EAACI/ GA2LEN/ EDF/ WAO guideline: EAACI/ GA(2)LEN/ EDF/ WAO guideline: definition, classification and diagnosis of urticaria. Allergy 2009;64:1417-26.

3. Wedi B. Urticaria. J Dtsch Dermatol Ges 2008;6:306-17. [CrossRef]

4. Kjaer HF, Eller E, Host A, Andersen KE, BinslevJensen C. The prevalence of allergic diseases in an unselected group of 6-year-old children. Pediatr Allergy Immunol 2008;19:737-45. [CrossRef]

5. Pite H, Wedi B, Borrego LM, Kapp A, Raap U. Management of childhood urticaria: current knowlege and practical recommendations. Acta Derm Venereol 2013;93:500-8. [CrossRef]

6. Bozkaya E. Parainfluenza, adeno, corona and rhinoviruses. ANKEM Derg 2006;20:248-53.

7. Ozdemir O. Idiopathic (autoimmune) chronic urticaria. Allergy Asthma Proc 2006;27:431-4. [CrossRef]

8. Özdemir Ö. Logical approach to a patient presenting with recurrent angioedema attacks. Klinik Tip Pediatri Dergisi 2019;11:64-73.

9. Volonakis M, Katsarou-Katsari A, Stratigos J. Etiologic factors in childhood chronic urticaria. Ann Allergy 1992;69:1-65.

10. Liu TH, Lin YR, Yang KC, Chou CC, Chang YJ, Wu HP. First attack of acute urticaria in pediatric emergency department. Pediatr Neonatol 2008;49:58-64. [CrossRef]

11. Cherry JD. Viral exanthems. Curr Probl Pediatr 1983;13:1-44.

12. Göncü EK, Aktan Ş, Atakan N, Başkan EB, Erdem T, Koca R, et al. The Turkish guideline for the diagnosis and management of urticaria-2016. Turkderm 2016;50:82-98. [CrossRef]

\section{Akut Ürtiker İle Başvuran Hastada Etiyolojik Ajan Olarak Saptanan Parainfluenza Virüs Tip 3}

Akut ürtiker şikâyeti ile başvuran ve bronşiolit geliştikten sonra alınan nazofaringeal sürüntüsünden parainfluenza virüs tip 3 (PiV-3) elde edilen II aylık kız hasta klinikte akut ürtikerde nadir saptanan bir etiyolojik ajan dolayısıyla sunulmuştur. Bir haftadır süren tüm vücutta makülo-papüler döküntüye benzer kızarıklık, nezle, ateş yüksekliği ve öksürük şikayeti ile dış merkeze götürülen hasta orada başlanan tedaviye rağmen döküntü şikâyetlerinin bir hafta içinde geçmeyip artış göstermesi nedeni ile çocuk allerji ve immünoloji polikliniğine getirildi. Hastanın yapılan fizik muayenesinde vücutta yaygın ve tedaviye cevap vermeyen ürtikeryal döküntüsü ve ileri inceleme tedavi amacı ile çocuk allerji ve immünoloji servisine yatışı yapıldı. Yatışının ikinci gününde ve bronşiolit geliştikten sonra yapılan değerlendirmede akciğerlerde iki taraflı subkrepitan ral ve hırıltı olması nedeni ile hastaya salbutamol $6 \times 0.15 \mathrm{mg} / \mathrm{kg} / \mathrm{doz}$ nebül verildi. Hastaya ürtiker için feniramin $1.4 \mathrm{mg} / \mathrm{kg} / \mathrm{gün}$ (iki dozda), ranitidin $2 \mathrm{mg} / \mathrm{kg} /$ gün (iki dozda) tedavisi başlandı. Alınan nazofarenks sürüntüsünde PiV-3 izole edildi. Çocukluk çağı akut ürtiker etiyolojisinde viral enfeksiyonların önemli bir yer tuttuğu unutulmamalıdır. Ürtikerle giden hastalıkların ayırıcı tanısında etiyolojik faktörler açısından ayrıntılı bir öykü ve enfeksiyona yönelik incelemelerin alınması gerekebilir.

Anahtar Sözcükler: Akut ürtiker; bronşiolit; parainfluenza. 